\title{
PENGEMBANGAN BAHAN AJAR BERBASIS KONSTRUKTIVISME PADA MATERI SISTEM PERSAMAAN LINEAR DUA VARIABEL
}

\section{DEVELOPING TEACHING MATERIAL BASED ON CONSTRUCTIVISM ON LINEAR EQUATION SYSTEM WITH TWO VARIABLES}

\author{
A. Sriyanti1), Destria Rafina Aziz'2), Ulfiani Rahman'3), Baharuddin'), Munirah'5) \\ 1,2,3,4,5)Fakultas Tarbiyah dan Keguruan UIN Alauddin Makassar \\ a.sriyanti@uin-alauddin.ac.id ${ }^{11}$, destriarafinaaziz12@gmail.com²), ulfiani.rahman@uin- \\ alauddin.ac.id ${ }^{3}$, baharuddin.abbas@uin-alauddin.ac.id ${ }^{4}$, , munirah@uin-alauddin.ac.id ${ }^{5)}$
}

\begin{abstract}
Abstrak
Tujuan penelitian ini adalah untuk mengetahui proses pengembangan bahan ajar berbasis konstruktivisme pada materi sistem persamaan linear dua variabel di kelas VIII SMP Negeri 3 Sungguminasa. Jenis penelitian yang dilakukan adalah penelitian dan pengembangan (Research and Development) dengan mengacu pada model pengembangan ADDIE yang terdiri atas 5 tahap sesuai namanya yaitu Analysis, Design, Development, Implementation, dan Evaluation. Penelitian ini dibatasi hanya sampai pada tahap pengembangan dan tahap implementasi yang hanya mengukur kevalidan dan tingkat kepraktisan bahan ajar menggunakan lembar validasi dan angket respons guru, tahap selanjutnya tidak dapat dilaksanakan disebabkan adanya pandemi Covid-19 yang mengharuskan peserta didik di rumahkan. Instrumen yang digunakan pada penelitian ini adalah lembar validasi dan angket respons guru. Berdasarkan hasil penelitian, diperoleh bahwa (1) hasil validasi untuk bahan ajar dan RPP adalah 4 dan 4,2 yang berada pada interval $3 \leq M \leq 4,5$ sehingga dikategorikan valid. (2) Praktis, tahap ini hanya menggunakan angket respons guru. Keseluruhan aspek berada pada kategori sangat positif dengan persentase $85 \%$ sehingga dapat disimpulkan bahwa bahan ajar berbasis konstruktivisme pada materi sistem persamaan linear dua variabel kelas VIII SMP Negeri 3 Sungguminasa memenuhi kriteria kevalidan dan kepraktisan.
\end{abstract}

Kata Kunci: bahan ajar, konstruktivisme, sistem persamaan linear dua variabel

\begin{abstract}
The purpose of this study was to determine the process of developing teaching material based on constructivism on linear equation system with two variables in class VIII SMP Negeri 3 Sungguminasa. The type of research is research and development (R\&D) by referring to the ADDIE development model which consist of 5 stages as the name implies, namely, Analysis, Design, Development, Implementation, and Evaluation. This research is limited to the development stage and the implementation stage which only measures the validity and practicality of teaching material using validation sheets and teacher response questionnaire, the next stage cannot be carried out due to covid-19 pandemic that requires learners to be sent home. The instruments used in this study were the validation sheet and the teacher response questionnaire. Based on the results of the study, it was found that (1) the validation results for teaching material and lesson plan were 4 and 4.2 which were at intervals of $3 \leq M \leq 4.5$ so that it is in valid category, (2) practice, this stage only uses teacher response questionnaire. All aspects in the very positive category with a percentage of 85\%. So, it can be concluded that teaching material based on constructivism on the linear equation system with two variables for class VIII SMP Negeri 3 Sungguminasa meet the validity and practicality criteria.
\end{abstract}


Keywords: teaching material, constructivism, linear equation system with two variables

How to Cite: Sriyanti, A., Aziz, D. R., Rahman, U., Baharuddin, \& Munirah. (2020). Pengembangan bahan ajar berbasis konstruktivisme pada materi sistem persamaan linear dua variabel. Al asma: Journal of Islamic Education, 2(2), 189-201.

\section{PENDAHULUAN}

Pendidikan sering diartikan sebagai usaha manusia untuk membina kepribadiannya sesuai dengan nilai-nilai di dalam masyarakat dan kebudayaannya (Hasbullah, 2012: 1). Selanjutnya pendidikan juga diartikan sebagai usaha yang dijalankan oleh seseorang atau kelompok orang lain agar menjadi dewasa untuk mencapai tingkat hidup atau kehidupan yang lebih tingi dalam arti mahal. Dalam dunia pendidikan, mutu pendidikan sangat berpengaruh terhadap sumber daya manusia ke depannya. Pendidikan di Indonesia diarahkan untuk membentuk peserta didik agar menjadi warga negara Indonesia guna mencapai bangsa Indonesia yang bermartabat. Penyelenggara pendidikan di sekolah yang melibatkan guru sebagai pendidik dan siswa sebagai peserta didik, diwujudkan dengan adanya interaksi belajar mengajar atau proses pembelajaran. Dalam penyelenggaraan ini guru diharuskan merencanakan pengajarannya secara terstruktur dan sistematis dan berpedoman pada seperangkat aturan tentang pedidikan yang dikemas dalam bentuk kurikulum.

Kurikulum merupakan alat pendidikan (Ibrahim, Abdullah, \& Mayawi, 2015: 1). Kurikulum berfungsi sebagai pedoman dalam pelaksanaan kegiatan pendidikan di sekolah bagi pihak-pihak yang terkait baik secara langsung maupun tidak langsung. Kurikulum berkembang di Indonesia sejak jaman kemerdekaan hingga sekarang ini yang berlaku kurikulum 2006 dan 2013. Implementasi kurikulum diterapkan dengan baik tergantung dari guru dan peserta didik. Guru memegang peran sentral terhadap proses dan hasil pendidikan karena guru merupakan subjek yang diharapkan mampu menterjemahkan kurikulum menjadi lebih operasional dalam bentuk silabus, RPP maupun bahan ajar. Salah satu komponen dalam pembelajaran yang memegang peran penting adalah materi ajar. Guru harus menyiapkan pembelajaran yang terstruktur dengan baik sehingga pembelajaran dapat terlaksana dan berpusat pada peserta didik. Selama proses belajar berlangsung, masalah belajar sering kali berkenaan dengan bahan belajar (materi) dan sumber belajar dikarenakan tidak semua sekolah memiliki fasilitas yang memadai baik bahan ajar berupa bahan tertulis maupun bahan tidak tertulis. Hal ini berlaku untuk semua mata pelajaran termasuk matematika (Yuliana, 2016: 183).

Matematika merupakan ilmu yang diperoleh dengan bernalar, yang menggunakan istilah yang didefinisikan dengan cermat, jelas dan akurat representasinya dengan lambang-lambang atau simbol yang memiliki arti (Siagian, 2017: 64). Matematika juga salah satu bidang keilmuan yang memiliki peran penting baik di sekolah maupun dalam kehidupan sehari-hari. Kegunaan dan manfaat mempelajari matematika dapat dirasakan dalam berbagai hal. Selain merupakan syarat kelulusan diberbagai jenjang baik SD, SMP, maupun SMA, matematika dapat ditetapkan dalam banyak hal seperti melakukan aktivitas perdagangan perihal jual beli yang selalu ditemui setiap hari. Karena alasan tersebut, matematika menjadi salah satu mata pelajaran yang wajib dipelajari peserta didik di sekolah, termasuk pada jenjang SMP. 
Namun pada kenyataannya, matematika nampaknya masih menjadi salah satu mata pelajaran yang paling tidak disukai oleh sebagian besar peserta didik, hal ini ditunjukkan pada pola pikir peserta didik yang masih menganggap matematika pelajaran yang relatif sulit yang membentuk kesan dan pengalaman negatif terhadap matematika serta rendahnya kualitas pembelajaran yang disediakan oleh guru di sekolah. Kualitas pembelajaran yang rendah disebabkan oleh banyak faktor salah satu penyebabnya karena kurang tepatnya pendekatan yang dipilih dalam mengembangkan silabus pembelajaran sehingga berdampak pada kurang efektifnya pembelajaran di kelas umumnya berdampak buruk terhadap hasil belajar matematika peserta didik.

Menurut Mullis dalam Prabawati (2018: 1) bahwa hasil pencapaian peserta didik pada mata pelajaran matematika juga masih tergolong rendah. Hal tersebut ditunjukkan dari hasil penelitian TIMSS dalam bidang matematika, secara keseluruhan Indonesia menempati urutan ke-38 dari 42 negara dengan skor 386, di bawah skor internasionalnya yaitu 500. Salah satu alternatif yang bisa digunakan untuk menyelesaikan permasalahan tersebut ialah dengan mengembangkan bahan ajar berbasis konstruktivisme agar peserta didik lebih berperan aktif .

Berdasarkan hasil observasi yang telah dilakukan di SMP Negeri 3 Sungguminasa pada kelas VIII maka diperoleh informasi bahwa guru hanya menggunakan buku paket matematika kurikulum 2013 ketika mengajar. Namun keberadaan buku paket juga belum mampu memberikan pemahaman yang maksimal dalam pemecahan masalah sehingga beberapa peserta didik menganggap bahwa materi matematika yang ada pada buku paket yang dipelajarinya masih bersifat abstrak untuk dipahami, ditambah lagi proses pembelajaran yang dilakukan di kelas masih menggunakan metode konvensional dengan maksud agar materi dapat tersampaikan dengan jelas. Bahasa yang sulit dipahami peserta didik jadi menambah kesulitan dan kejenuhan peserta didik dalam belajar. Kurangnya minat peserta didik dalam memperhatikan materi pembelajaran dan kebanyakan peserta didik menganggap bahwa pembelajaran matematika sulit dipahami mengakibatkan pencapaian hasil belajar peserta didik berada di bawah kriteria ketuntasan minimal yang ditetapkan di sekolah (Wahida, 5 Juni 2019). Sementara itu, saat mengerjakan tugas baik tugas sekolah maupun tugas rumah, peserta didik akan berusaha sekeras mungkin dalam menyelesaikan tugas tersebut dengan cara meminta bantuan dari peserta didik lainnya yang dianggap mampu yang jumlahnya kurang lebih 5 orang per kelas. Sehingga ketika ulangan peserta didik akan mengalami kesulitan sebab selama proses pembelajaran berlangsung peserta didik kurang memperhatikan penjelasan guru dan hanya mengandalkan teman dalam mengerjakan tugas. Ini merupakan penyebab hasil belajar peserta didik tidak sesuai dengan yang diharapkan. Hal ini terjadi pada sebagian besar materi dalam matematika. Salah satunya adalah materi sistem persamaan linear dua variabel.

Menurut Hutagaol (2013: 86) pembelajaran matematika bagi para peserta didik merupakan suatu proses pembentukan pola pikir dalam pemahaman suatu pengertian maupun dalam penalaran suatu hubungan antara pengertian-pengertian tersebut. Sasaran pembelajaran matematika disetiap jenjang pendidikan diantaranya adalah mengembangkan kemampuan peserta didik dalam berpikir matematis. Pengembangan kemampuan ini sangat diperlukan agar peserta didik lebih memahami konsep yang dipelajari, dan dapat menerapkannya dalam berbagai situasi. 
Adapun konsep pembelajaran matematika menurut pandangan teori belajar konstruktivisme yaitu menuntut guru untuk lebih profesional pada bidangnya. Misalnya bagaimana cara guru menciptakan kondisi pembelajaran yang dimulai dari isu-isu yang relevan dengan lingkungan anak. Selain itu, guru dituntut untuk lebih terampil dalam memilih topik yang dapat membangkitkan motivasi anak selama pembelajaran berlangsung (Siahaan, 2005: 21). Sumarsih (2009: 55) memberikan definisi terhadap konsep pembelajaran konstruktivistik atau konstruktivisme sebagai salah satu aliran filsafat yang lebih memberikan penekanan bahwa pengetahuan merupakan hasil dari konstruksi. Paradesa dalam Oktavianti \& Putra (2018: 97) menyatakan bahwa konstruktivisme adalah suatu pendekatan yang berkeyakinan bahwa orang secara aktif membangun atau membuat pengetahuan sendiri dan realitas ditentukan oleh pengalaman orang itu sendiri.

Menurut teori konstruktivisme, belajar adalah kegiatan yang aktif dimana si subjek belajar membangun sendiri pengetahuannya. Subjek belajar juga mencari sendiri makna dari sesuatu yang mereka pelajari. Penerapan di kelas, misalnya saat peserta didik sedang bekerja atau praktik mengerjakan sesuatu, memecahkan masalah, berlatih keterampilan secara fisik, menulis karangan, membaca, teks, kemudian menuliskan isi kesimpulannya, mendemostrasikan dan sebagainya. Untuk lebih menghidupkan suasana kelas, memang dituntut kreativitas pendidik (Rafiqah, 2013: 124). Konstruktivisme adalah salah satu pembelajaran yang memberikan peluang terjadinya proses aktif peserta didik mengkonstruksi atau membangun sendiri pengetahuannya dalam proses pembelajaran. Ciri penting konstruktivisme dalam proses belajar mengajar peserta didik aktif menemukan sendiri konsep-konsep yang perlu diketahui.

Sanjaya dalam Hidayanto, Taufiq, \& Irawan (2013: 2) berpendapat bahwa pembelajaran dapat dipandang dari dua dimensi, yaitu sebagai proses penyampaian materi dan sebagai proses pengaturan lingkungan agar peserta didik dapat belajar. Pembelajaran merupakan proses penyampaian materi artinya guru menyampaikan materi dengan bantuan bahan ajar sedangkan pembelajaran merupakan proses pengaturan lingkungan agar peserta didik dapat belajar artinya guru memberikan berbagai bahan ajar yang dapat mendorong peserta didik untuk belajar. Dalam hal ini terlihat betapa pentingnya penggunaan bahan ajar dalam proses pembelajaran.

Bahan ajar merupakan salah satu faktor penting dalam menunjang kefektifan suatu proses pembelajaran. Adapun definisi bahan ajar sebagaimana yang diungkapkan oleh (Depdiknas, 2006) bahwa bahan ajar merupakan segala bentuk bahan yang digunan untuk membantu guru/instruktur dalam melaksanakan kegiatan pembelajaran di kelas, baik berupa bahan tertulis seperti hand out, buku, modul, lembar kerja peserta didik, brosur, leaflet, wallchart, maupun bahan tidak tertulis seperti video/film, VCD, radio, kaset, CD interaktif berbasis komputer dan internet.

Berdasarkan uraian di atas, maka salah satu cara yang dapat dilakukan dalam menyelesaikan permasalahan di atas adalah dengan mengembangkan bahan ajar berbasis konstruktivisme agar peserta didik lebih berperan aktif dalam proses pembelajaran dan menjalani proses pembelajaran yang lebih bermakna karena dibuat berdasarkan kenyataan yang ada di lingkungan peserta didik. Selain itu, peserta didik juga memegang peran penting dalam menemukan konsep, teorema, rumus, dan lain sebagainya sehingga materi pelajaran akan lebih mudah dipahami. 
Hal ini sejalan dengan penelitian yang dilakukan oleh Setiawan (2016) mengenai "pengembangan bahan ajar matematika bab integral berbasis konstruktivisme pada siswa kelas XII IPA". Dari hasil analisis menunjukkan bahwa bahan ajar ini memenuhi kriteria keefektifan karena jumlah peserta didik yang memperoleh nilai $>75$ mencapai $80 \%$. Dapat disimpulkan bahwa pembelajaran ini sudah baik dan memenuhi rata-rata ketuntasan hasil belajar. Oleh karena itu, penelitian ini bertujuan untuk mengetahui proses pengembangan bahan ajar berbasis konstruktivisme pada materi sistem persamaan linear dua variabel yang valid dan praktis di kelas VIII SMP Negeri 3 Sungguminasa. Penelitian yang sama juga dilakukan oleh Judding (2018) mengenai "Pengembangan Bahan Ajar Pendidikan Agama Islam Berbasis Pendekatan Konstruktivisme pada Materi Berani Hidup Jujur kela XI SMAN 2 Gowa", dengan hasil penelitian yang menunjukkan bahwa modul yang dikembangkan dengan pendekatan konstruktivisme layak digunakan berdasarkan aspek kevalidan, kepraktisan, dan keefektifan dan mampu meningkatkan prestasi belajar peserta didik.

\section{METODE PENELITIAN}

Jenis penelitian yang digunakan adalah penelitian dan pengembangan (research and development). Research and development adalah sebuah proses penelitian yang digunakan untuk mengembangkan dan memvalidasi produk pendidikan. Hasil dari penelitian pengembangan tidak hanya pengembangan sebuah produk yang sudah ada melainkan juga untuk menemukan pengetahuan atau jawaban atas permasalahan praktis. Menurut Sugiyono (2015: 32) mengemukakan bahwa penelitian pengembangan memiliki 4 tingkat kesulitan, yaitu meneliti tanpa membuat dan menguji produk, tanpa meneliti hanya menguji produk yang telah ada, meneliti dan mengembangkan produk yang telah ada, meneliti dan menciptakan produk baru.

Peneliti menggunakan penelitian dan pengembangan pada level yang tingkatannya sedang yaitu level 3 dimana peneliti melakukan penelitian untuk menghasikan rancangan dilanjutkan dengan mengembangkan produk tanpa mengujinya. Model pengembangan yang dipilih pada penelitian ini adalah model pengembangan ADDIE yang terdiri dari 5 tahap yaitu tahap analisis (analysis), desain (design), pengembangan (develop), implementasi (implement), evaluasi (evaluation) (Molenda, 2003: 1). Produk yang akan dikembangkan pada penelitian ini adalah bahan ajar pada materi sistem persamaan linear dua variabel peserta didik SMP Negeri 3 Sungguminasa.

Model ADDIE dipilih karena tahapan yang ada dalam model ini sangat cocok dalam penelitian dan pengembangan bahan ajar yang akan dilakukan oleh peneliti. Tahapan pengembangan model ADDIE ini sangat spesifik dan sistematis sehingga tiap tahapan mampu dilaksanakan dengan baik untuk memperoleh produk yang baik. Tahapan kegiatan dalam model pengembangan ADDIE pada dasarnya memiliki kaitan satu sama lain. Karena memiliki kaitan maka setiap tahapan perlu dilakukan secara menyeluruh dan sistematis (Pribadi, 2014: 23). Menurut Gafur (2012: 39-40) model pengembangan ADDIE terdiri dari 5 tahapan yaitu:

a) Analisis (Analysis)

Analisis dilakukan untuk menentukan kebutuhan belajar, apa yang akan diajarkan, dan kompetensi apa yang diharapkan dikuasai peserta didik setelah belajar. Siswono (2019: 238) menjelaskan bahwa tahap analisis umumnya membahas tentang hal-hal sebagai berikut: 
1) Latar belakang keseluruhan dari peserta didik seperti usia, pengalaman masa lalu, tingkat pengetahuan, dan lain sebagainya.

2) Kebutuhan peserta didik untuk menyelesaikan akhir program pembelajaran atau apa kebutuhan peserta didik.

3) Kegiatan peserta didik dari hasil pembelajaran, apakah pengetahuan, keterampilan, sikap, perilaku, dan lain-lain.

4) Strategi pembelajaran yang digunakan untuk peserta didik cukup atau ada hal-hal yang perlu ditambahkan, diklarifikasi, dan diperbaiki.

5) Fokus tujuan instruksional.

6) Lingkungan belajar kondusif atau tidak.

7) Jenis lingkungan pembelajaran yang lebih disukai peserta didik.

8) Sumber daya berupa teknis maupun dukungan sudah mencukupi atau tidak.

b) Desain (Design)

Kegiatan yang dilakukan pada tahap desain meliputi: merumuskan kompetensi (tujuan pembelajaran khusus), menentukan materi pembelajaran, strategi, media, evaluasi, dan sumber. Kegiatan desain dilakukan untuk merumuskan konsep bahan ajar baru yang akan dibuat. Bahan ajar dalam hal ini berupa modul. Tahap perancangan ini dimulai dari menetapkan tujuan pembelajaran, merancang skenario pembelajaran, merancang materi bahan ajar, dan merancang alat evaluasi hasil belajar.

c) Pengembangan (Develop)

Langkah pengembangan berupa memproduksi atau membuat atau mewujudkan spesifikasi pembelajaran yang telah ditentukan pada tahap desain. Isi bahan ajar yang telah dirancang akan mulai dikembangkan pada tahap ini. Pada tahap desain telah disusun kerangka konseptual bahan ajar yang akan dibuat, pada tahap pengembangan inilah kerangka yang masih konseptual tersebut akan direaliasikan menjadi produk yang siap untuk diimplementasikan.

d) Implementasi (Implement)

Setelah paket pembelajaran dikembangkan pada tahap 3, langkah berikutnya adalah memanfaatkan atau menggunakan produk yang telah dikembangkan dalam kegiatan pembelajaran. Hal yang perlu dipersiapkan pada tahap ini adalah jadwal, penyiapan ruang kelas, alat dan media, menyiapkan peserta didik secara fisik maupun mental. Bahan ajar yang telah dikembangkan akan diterapkan pada situasi nyata yaitu di kelas. Selama proses implementasi ini akan ditampung berbagai saran dan komentar baik dari peserta didik maupun guru.

Namun, bahan ajar yang sudah dinyatakan valid dan praktis yang siap diuji cobakan pada peserta didik kelas VIII SMP Negeri 3 Sungguminasa tidak dapat dilakukan disebabkan saat peneliti siap melakukan uji coba terjadi hal yang tidak diinginkan, yaitu pandemi covid-19 yang mengharuskan semua peserta didik di rumahkan. Peneliti sempat mengajukan uji coba daring ke sekolah namun tidak dapat dilaksanakan sebab menemui beberapa kendala, yaitu:

a. Proses belajar mengajar daring harus menggunakan aplikasi zoom agar seluruh aspek yang telah dirancang melalui RPP dapat dimaksimalkan namun peserta didik SMP Negeri 3 Sungguminasa hanya menggunakan HP orangtua.

b. Aplikasi zoom memerlukan banyak penggunaan kuota sehingga pihak sekolah tidak menyetujui karena akan membebani peserta didik dan orang tua peserta didik. Bahkan 
proses pembelajaran yang dilakuakan oleh guru mata pelajaran matematika di sekolah tersebut hanya mengirim materi dan tugas kepada peserta didik tanpa bertatap muka secara daring.

Sehingga penelitian ini hanya sampai pada tahap implementasi yang hanya menggunakan angket respons guru dengan melakukan validasi oleh tim ahli yang merupakan dosen matematika uin alauddin Makassar dan guru SMP Negeri 3 Sungguminasa dan memberikan angket respons guru kepada guru matematika di sekolah. e) Evaluasi (Evaluation)

Evaluasi disini meliputi internal and external evaluation. Evaluasi internal (evaluasi formatif) dilaksanakan untuk mengetahui efektifitas dan kualitas pembelajaran. Hasil evaluasi internal digunakan sebagai umpan balik untuk mengadakan perbaikan. Evaluasi eksternal (evaluasi sumatif) dimaksudkan untuk mengetahui tingkat penguasaan peserta didik terhadap kompetensi yang telah diajarkan. Saran dan komentar dari peserta didik dan guru selanjutnya dijadikan sebagai bahan evaluasi untuk mengadakan perbaikan demi menyempurnakan bahan ajar yang telah dibuat. Revisi akan dibuat sesuai dengan hasil evaluasi berupa kekurangan dan kebutuhan yang belum dipenuhi pada bahan ajar yang telah dibuat.

Namun tahapan ini tidak dapat dilakukan karena penelitian ini hanya sampai pada tahap implementasi yang hanya menggunakan angket respons guru dan tidak mengimplementasikan langsung dengan peserta didik dengan produk yang telah dikembangkan dalam kegiatan pembelajaran di sekolah.

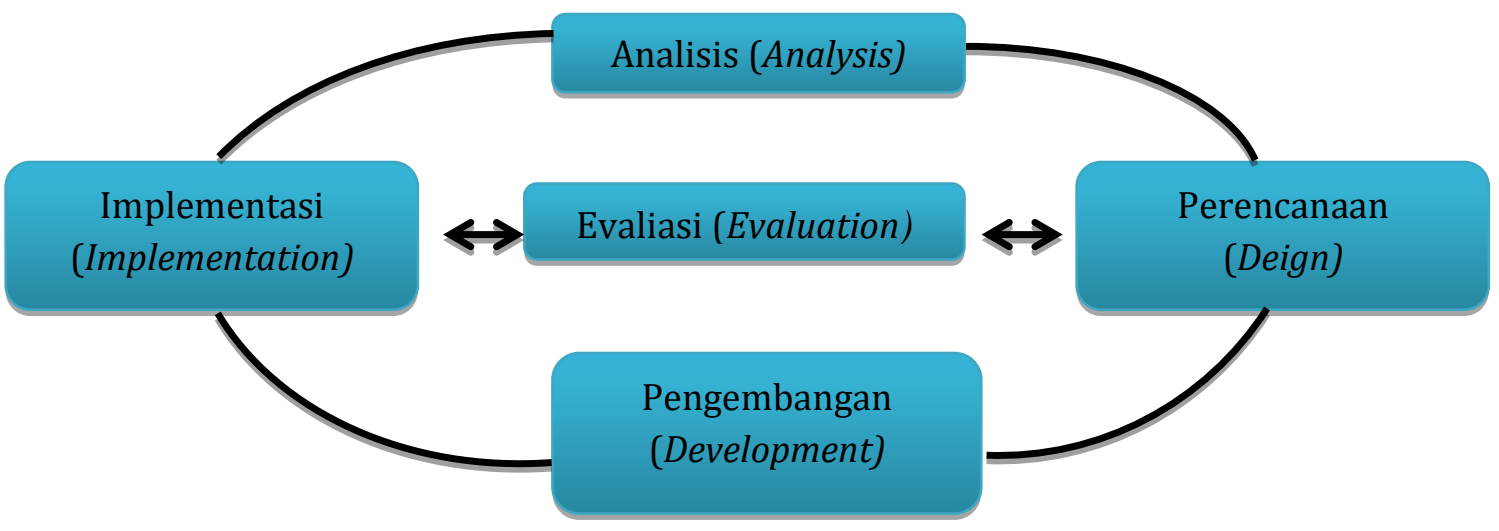

Gambar 1: Desain Pengembangan ADDIE

Subjek uji coba produk pengembangan bahan ajar adalah peserta didik kelas VIII SMP Negeri 3 Sungguminasa Kabupaten Gowa, Sulawesi Selatan. Teknik pengumpulan data yang digunakan pada penelitian ini berupa angket. Instrumen pengumpulan data yang digunakan pada penelitian ini berupa lembar validasi, angket respons guru. Teknik analisis data untuk lembar validasi menggunakan skala likert (1 sampai 5) yang diisi oleh tim validator. Hasil validitas instrumen diketahui dengan melihat rata-rata total kevalidan instrumen berdasarkan kriteria kevalidan yang dapat diamati pada tabel 1 (Arsyad, 2016: 159). Instrumen dikatakan valid dan dapat digunakan jika tingkat kevalidan total menunjukkan kriteria valid. Jika tidak memenuhi maka perlu dilakukan revisi dan validasi ulang. Lembar validasi ini dugunakan untuk mengetahui tingkat kevalidan bahan ajar pembelajaran yang dikembangkan. 
Tabel 1. Kriteria Kevalidan Bahan Ajar

\begin{tabular}{cc}
\hline Interval Skor & Kriteria \\
\hline $4.3 \leq \mathrm{M} \leq 5$ & Sangat Valid \\
$3.5 \leq \mathrm{M}<4.3$ & Valid \\
$2.7 \leq \mathrm{M}<3.5$ & Cukup Valid \\
$1.9 \leq \mathrm{M}<2.7$ & Kurang Valid \\
$\mathrm{M}<1.9$ & Tidak Valid \\
\hline
\end{tabular}

Teknik analisis data untuk angket respons guru menggunakan skala likert (SS sampai TS) yang diisi oleh guru diakhir berdasarkan bahan ajar yang dikembangkan. Jika hasil respons guru belum menunjukkan kriteria positif (70\%) maka perlu dilakuakan revisi berdasarkan masukan dari guru. Angket respons guru ini digunakan untuk mengetahui tingkat kepraktisan bahan ajar yang dikembangkan.

\section{HASIL DAN PEMBAHASAN}

\section{Tahap Analisis (Analysis)}

Tahap analisis merupakan hal mendasar yang perlu dilakukan dalam penelitian, khususnya penelitian pengembangan yang menggunakan model pengembangan ADDIE. Tahap ini merupakan tahap awal untuk mengidentifikasi dan mengetahui masalah yang dihadapi oleh siswa dan guru dalam pembelajaran matematika. Analisis dilakukan untuk menentukan kebutuhan belajar, apa yang akan diajarkan, dan kompetensi apa yang diharapkan dikuasai peserta didik setelah belajar.

Masalah mengenai bahan ajar yang digunakan di sekolah diperoleh melalui wawancara terhadap salah satu guru mata pelajaran matematika pada 30 April 2020 beliau hanya menggunakan buku paket matematika kurikulum 2013 ketika mengajar. Namun keberadaan buku paket juga belum mampu memberikan pemahaman yang maksimal dalam pemecahan masalah sehingga beberapa peserta didik menganggap bahwa materi matematika yang ada pada buku paket yang dipelajarinya masih bersifat abstrak untuk dipahami, ditambah lagi proses

Pembelajaran yang dilakukan di kelas masih berpusat pada dengan menggunakan metode konvensional dengan maksud agar materi dapat tersampaikan dengan jelas. Tampilan dan isi kurang menarik, bahasa yang sulit dipahami peserta didik jadi menambah kesulitan dan kejenuhan peserta didik dalam belajar. Kurangnya minat peserta didik dalam memperhatikan materi pembelajaran dan kebanyakan siswa menganggap bahwa pembelajaran matematika sulit dipahami mengakibatkan pencapaian hasil belajar peserta didik berada di bawah kritetia ketuntasan minimal yang ditetapkan di sekolah

Guru mata pelajaran yang menggunakan metode konvensional menyebabkan peserta didik tidak tertarik dalam proses belajar dan hanya tertarik saat diberi tugas karena mencemaskan hasil yang peserta didik dapatkan saat pemberian tugas. Sehingga peserta didik akan berupaya mengerjakan tugas dengan meminta bantuan peserta didik lainnya yang mereka anggap mampu. Akibatnya saat diadakan evaluasi, hanya sebagian peserta didik yang mampu mencapai hasil yang diharapkan. Hal ini dialami peserta didik pada sebagian besar materi matematika termasuk sistem persamaan linear dua variabel. Buku paket yang hanya tersedia di perpustakaan dengan jumlah terbatas serta proses pembelajaran yang berpusat pada guru menyebabkan rendahnya minat belajar peserta 
didik. Hal ini juga menyebabkan peserta didik hanya belajar saat proses belajar mengajar di kelas dan tidak memiliki ketertarikan untuk belajar mandiri di rumah.

\section{Tahap Desain (Design)}

Tahap selanjutnya merupakan tahap perancangan bahan ajar baru yang didesain untuk menjawab tiap permasalahan yang ditemukan pada tahap analisis. Pada tahap ini akan dirancang Rencana Pelaksanaan Pembelajaran (RPP) dan bahan ajar.

a. RPP

Kegiatan pembelajaran yang akan dilakukan dalam proses belajar mengajar di kelas sudah harus disusun secara matang melalui RPP. Komponen RPP mencakup: (1) Identitas yang terdiri atas identitas sekolah, mata pelajaran, kelas, semester, materi pembelajaran, dan alokasi waktu. (2) Kompetensi inti kompetensi dasar yang diperoleh pada silabus, indikator pencapaian yang disusun menggunakan Taksonomi Bloom, tujuan, materi, metode, media, alat, dan sumber pembelajaran. (3) Langkah pembelajaran yang terdiri atas kegiatan pendahuluan, inti, dan penutup.

b. Bahan ajar

Bahan ajar dirancang semenarik mungkin dengan berbasis konstruktivisme dengan memberikan penekanan pemahaman konsep sehingga peserta didik mampu melakukan pemecahan masalah. Berikut rancangan isi bahan ajar yang akan dibuat:

1) Judul, pemilihan judul sesuai dengan nama mata pelajaran, isi materi yang menekankan pemahaman konsep dalam pemecahan masalah, dan subjek yang ditujukan yaitu "Modul Matematika: Sistem Persamaan Linear Dua Variabel untuk Kelas VIII SMP/MTs",

2) Kata Pengantar, bagian ini berisi ucapan syukur dan terima kasih penulis atas terealisasinya bahan ajar ini, serta alasan penulisan bahan ajar. Tak lupa penulis mengharapkan kritik dan saran yang membangun untuk kesempurnaan bahan ajar ini dan sebagai pembelajaran bagi penulis kedepannya,

3) Sajian bahan ajar, bagian ini berisi gambaran besar berbagai isi berupa kolom ingin belajar apa?, catatan, kata kunci, example, tips belajar, refleksi, alternative pemecahan masalah, latihan, ayo memahami, ayo mengingat, dan ilustrasi yang menekankan pemahaman konsep.

4) Daftar Isi, bagian ini akan memudahkan pengguna untuk menemukan materi tanpa membuka halaman demi halaman,

5) Kompetensi Dasar dan Tujuan Pembelajaran, bagian ini memudahkan pengguna mengetahui apa yang ingin dicapai selama mempelajari materi yang disajikan,

6) Peta Konsep, bagian ini berisi gambaran materi yang akan dibahas selama mempelajari bahan ajar ini,

7) Tes Diagnosis kesiapan, bagian ini akan membantu peserta didik untuk mengingat kembali materi sebelumnya yang tentunya memiliki kaitan dengan materi yang akan dibahas pada bahan ajar ini, dan mampu mengingat konsep awal sistem persamaan linear dua variabel.

8) Uraian Materi, bagian ini berisi ilustrasi-ilustrasi yang akan membantu peserta didik menemukan konsep dan rumus serta menggunakannya dalam menyelesaiakan masalah yang akan mereka buat sendiri, dimana pendekatan yang saya gunakan pada isi materi ini yaitu pendekatan konstruktivisme yang mana 
pendekatan ini lebih menekankan terhadap pemahaman konsep peserta didik agar mampu menyelesaiakan suatu pemecahan masalah.

9) Rangkuman, bagian ini berisi ringkasan konsep dan rumus agar peserta didik bisa mencocokkan konsep dan rumus yang sudah mereka peroleh sendiri,

10) Uji Kompetensi, bagian ini berisi soal-soal untuk mengukur pemahaman konsep peserta didik setelah menggunakan bahan ajar ini.

11) Daftar Pustaka, bagian ini berisi daftar referensi peneliti yang dijadikan rujukan dalam penulisan bahan ajar,

12) Riwayat Hidup Penulis, bagian ini berisi data diri penulis.

\section{Tahap Pengembangan (Development)}

Tahap pengembangan merupakan tahap merealisasikan apa yang sudah dirancang pada tahap desain. Pada tahap ini peneliti mulai membuat RPP dan bahan ajar berbasis kontruktivisme sesuai dengan struktur yang telah dirancang pada tahap desain. Adapun bahan ajar tersebut terdiri atas satu bab yaitu Sistem Persamaan Linear Dua Variabel (SPLDV) dengan lima sub bab yaitu persamaan linear satu variabel, persamaan linear dua variabel, sistem persamaan linear dua variabel, model sistem persamaan linear dua variabel dan metode penyelesaian sistem persamaan linear dua variabel. Selain bahan ajar, juga dilakuakan pengembangan RPP untuk menunjang penggunaan bahan ajar. Selanjutnya RPP dan bahan ajar tersebut divalidasi oleh tim ahli dan guru (validator) beserta instrumen penelitian lainnya yaitu angket respons guru kemudian direvisi berdasarkan komentar dan saran dari tim ahli dan guru (validator).

Validator yang melakukan validasi terhadap perangkat penelitian terdiri atas dua orang yang merupakan dosen Jurusan Pendidikan Matematika UIN Alauddin Makassar dan salah satu guru matematika SMP Negeri 3 Sungguminasa. Validator memberi saran perbaikan serta penilaian sebelum perangkat penelitian digunakan pada tahap selanjutnya. Setelah melakukan perbaikan dan validasi sebanyak 3 tahap, maka tim ahli memberi penilaian pada perangkat penelitian yang telah dibuat pada lembar validasi yang telah disediakan. Hasil penilaian tim ahli dapat dilihat pada tabel 2.

Tabel 2. Hasil Penilaian oleh Tim Ahli dan Guru

\begin{tabular}{ccc}
\hline Perangkat Penelitian & Skor Rata-rata & Kriteria \\
\hline RPP & 4 & Valid \\
Bahan Ajar & 4.2 & Valid \\
Angket Respons Guru & 4.3 & Sangat Valid \\
\hline Rata-rata total kevalidan instrumen & 4.2 & Valid \\
\hline
\end{tabular}

Berdasarkan tabel 2, hasil analisis penilaian tim ahli terhadap perangkat penelitian yang dikembangkan diperoleh nilai rata-rata 4,2 dan berada pada kategori valid. Selain itu, validator pertama, kedua dan ketiga menyimpulkan bahwa perangkat penelitian dapat digunakan dengan revisi kecil. Hal ini menandakan RPP, bahan ajar dan angket respons guru layak untuk diuji cobakan.

\section{Tahap Implementasi (Implement)}

Tahap selanjutnya adalah tahap menggunakan produk yang telah dikembangkan dalam proses belajar mengajar. Meski sudah siap digunakan dalam proses belajar 
mengajar, terdapat kondisi yang sangat tidak memungkinkan pelaksanaan uji coba tersebut yaitu adanya pandemi yang mengharuskan semua peserta didik di rumahkan, sehingga yang diuji dari pengembangan bahan ajar ini hanya tingkat kepraktisannya. Tingkat kepraktisan diukur menggunakan angket respons guru yang diperoleh setelah mempresentasekan produk yang dilakukan secara online dan diperoleh hasil $85 \%$ dengan 10 aspek penilaian. Angka 85\% ini berada pada kategori sangat positif.

Peneliti mengajukan uji coba online ke sekolah namun tidak dapat dilaksanakan sebab menemui beberapa kendala, yaitu: (a) Proses belajar mengajar online harus menggunakan aplikasi zoom agar seluruh aspek yang telah dirancang melalui RPP dapat dimaksimalkan namun siswa SMP Negeri 3 Sungguminasa hanya menggunakan HP orangtua. (b) Aplikasi zoom memerlukan banyak penggunaan kuota sehingga pihak sekolah tidak menyetujui karena akan membebani peserta didik dan orang tua peserta didik. Bahkan guru mata pelajaran matematika di sekolah tersebut hanya mengirim materi dan tugas kepada peserta didik.

Penelitian ini hanya menguji kevalidan dan kepraktisan bahan ajar. Kevalidan yang diukur menggunakan lembar validasi yang diisi oleh tim validator dan kepraktisan hanya memuat angket respons guru yang diisi oleh guru mata pelajaran. Angket respons guru ini tidak serta merta diisi oleh guru mata pelajaran melainkan peneliti mengirim bahan ajar dan mendeskripsikan isinya lalu guru mata pelajaran mengisi angket respons guru via online melalui whatsapp untuk selanjutnya dipindahkan oleh peneliti pada angket respons guru yang sudah divalidasi oleh validator. Pengisian angket respons guru ini dilakukan pada Jumat, 3 Mei 2020 oleh salah satu guru mata pelajaran matematika kelas VIII yaitu Ibu Wahidah, S,Pd.I dan diperoleh hasil respons guru sebesar 85\% dengan 10 aspek penilaian. Angka 85\% ini berada pada interval 85\% $\leq$ RG $\leq 100$ dan dikategorikan Sangat Positif.

Penelitian yang dilakukan oleh Oni Pluntur Artiano (2015) mengenai pengembangan buku ajar dengan pendekatan konstruktivisme untuk meningkatkan kemampuan komunikasi matematis menunjukkan bahwa bahan ajar yang dikembangkan menggunakan pendekatan konstruktivisme telah memenuhi standar kualitas yang ditetapkan dan layak untuk digunakan (Artiono, 2015: 4). Hal ini selaras dengan penelitian yang dilakukan oleh Mariana Judding (2018) bahwa modul yang dikembangkan dengan pendekatan konstruktivisme layak digunakan berdasarkan aspek kevalidan, kepraktisan, dan keefektifan dan mampu meningkatkan prestasi belajar siswa (Judding, 2018: 5). Hal ini juga selaras dengan penelitian yang dilakukan oleh Deby Sarah, Risnawati, \& Zubaidah Amir (2018) modul yang dikembangkan dengan pendekatan Konstruktivisme menunjukkan bahwa produk yang dikembangkan tersebut memenuhi kriteria kevalidan dengan kategori sangat valid tanpa revisi dan layak digunakan pada proses pembelajaran (Sarah, Risnawati, \& Amir, 2018: 199). Hal ini dikarenakan bahan ajar berbasis konstruktivisme yang dikembangkan dengan lebih menekankan pemahaman konsep dalam pemecahan masalah yang sesuai dengan realitas dan lingkungan peserta didik sehingga dapat membuat pembelajaran lebih mudah dipahami.

Oktavianti \& Putra (2018: 97) mengungkapkan bahwa orang secara aktif membangun atau membuat pengetahuan sendiri dan realitas ditentukan oleh pengalaman orang itu sendiri artinya dalam proses belajar mengajar peserta didik aktif menemukan sendiri konsep-konsep yang perlu diketahui melalui ilustrasi-ilustrasi yang diberikan agar 
peserta didik dapat membuat pembelajaran lebih bermakna. Pemahaman yang diperoleh akan bertahan lebih lama daripada sekedar menghafalkan konsep lalu menggunakannya dalam penyelesaian masalah.

Bahan ajar yang dikembangkan memiliki beberapa kelebihan diantaranya menggunakan ilustrasi berupa hal-hal yang terjadi di lingkungan peserta didik agar peserta didik mudah membayangkan dan menemukan konsep yang terdapat dalam ilustrasi tersebut. Selain itu, gambar yang disajikan juga bukan merupakan gambar animasi melainkan gambar nyata yang ada di sekitar peserta didik. Isi dari bahan ajar ini lebih lengkap diantaranya judul, kata pengantar, sajian bahan ajar (catatan, kata kunci, example, tips belajar, refleksi, alternatif pemecahan masalah, ayo memahami, ayo mengingat, ilustrasi-ilustrasi yang menekankan pemahaman konsep, dan uji kemampuan individu maupun kelompok), daftar isi, kompetensi dasar, tujuan pembelajaran, peta konsep, tes diagnosis kesiapan, uraian materi, rangkuman, uji kompetensi , daftar pustaka, dan riwayat hidup penulis. Sementara, kekurangan dari bahan ajar ini yaitu bahan ajar ini masih berbentuk media cetak sehingga dapat diperbarui dengan membuat bahan ajar dalam bentuk media elektronik.

\section{SIMPULAN}

Berdasarkan hasil penelitian dan pembahasan, secara umum dapat disimpulkan bahwa telah dihasilkan bahan ajar berbasis pendekatan kontruktivisme pada materi sistem persamaan linear dua variabel yang valid dan praktis untuk digunakan bagi peserta didik kelas VIII SMP Negeri 3 Sungguminasa. Valid terlihat dari penilaian tim ahli dimana hasil analisis penilaian tim ahli terhadap perangkat penelitian yang dikembangkan diperoleh nilai rata-rata 4,2 dan berada pada kategori valid. Sedangkan praktis terlihat dari angket respons guru dimana diperoleh hasil angket respons guru sebesar 85\% dengan 10 aspek penilaian. Angka 85\% ini berada pada interval 85\% $\leq \mathrm{RG} \leq 100$ dan dikategorikan sangat positif sehingga dapat disimpulkan bahwa bahan ajar yang dikembangkan memenuhi kriteria kevalidan dan kepraktisan. Pada penelitian ini hanya mengukur tingkat kevalidan dan kepraktisan sehingga penelitian selanjutnya diharapkan dapat menggunakan 5 tahap model penelitian pengembangan ADDIE secara lengkap dan sempurna agar tingkat efektivitas produk dapat diukur.

\section{DAFTAR PUSTAKA}

Artiono, O. P. (2015). Pengembangan buku ajar matematika dengan pendekatan konstruktivisme untuk siswa kelas V SDIT Internasional Luqman AL-Hakim Yogyakarta kelas Bilingual. Jurnal Pengembangan Bahan Ajar, 1-10.

Depdiknas. (2006). Pedoman memilih dan menyusun bahan ajar. Jakarta: Depdiknas.

Gafur, A. (2012). Desain pembelajaran: konsep, model, dan aplikasinya dalam perencanaan pelaksanaan pembelajaran. Yogyakarta: Penerbit Ombak.

Hasbullah. (2012). Dasar-dasar ilmu pendidikan (Cet. 10). Jakarta: Rajawali Pres.

Hidayanto, Taufiq, \& Irawan, E. B. (2013). Pengembangan bahan ajar berbasis realistik mathematic education untuk membangun kemampuan komunikasi matematis peserta didik SMP Kelas VIII pada materi fungsi. Jurnal Universitas Negeri Malang. Retrieved from http://jurnal-daring.um.ac.id. 
Hutagaol, K. (2013). Pembelajaran kontekstual untuk meningkatkan kemampuan representasi matematis siswa Sekolah Menengah Pertama. Jurnal Ilmiah Program Studi Matematika, 2(1).

Ibrahim, A., Abdullah, I., \& Mayawi. (2015). Pengertian, peran dan fungsi kurikulum. Retrieved from https://www.slideshare.net/mobile/mayawi/pengertian45817652.

Judding, M. (2018). Pengembangan bahan ajar pendidikan agama islam berbasis pendekatan konstruktivisme pada materi berani hidup jujur kelas XI SMAN 2 Gowa.

Molenda, M. (2003). Educational technology: an encyclopedia. Retrieved from http://www.indiana.edu/molpage/The ADDIE Model_Encyclo.pdf.

Oktavianti, S. F., \& Putra, F. G. (2018). Implementasi model osborn dengan teknik mnemonic melalui teori konstruktivisme terhadap kemampuan pemecahan masalah matematis. Mapan: Jurnal Matematika Dan Pembelajaran, 6(1), 95-103. https://doi.org/10.24252/mapan.2018v6n1a9.

Prabawati, D. (2018). Penerapan model pembelajaran Search, Solve, Create, And Share (SSCS) berbasis Realistic Mathematics Education (RME) untuk meningkatkan kemampuan representasi matematis siswa SMP. Universitas Pendidikan Indonesia.

Pribadi, B. A. (2014). Desain dan pengembangan program pelatihan berbasis kompetensi: implementasi model ADDIE. Jakarta: Kencana.

Rafiqah. (2013). Pengembangan perangkat pembelajaran berbasis konstruktivisme (Cet. I). Makassar: Uin Alauddin Press.

Sarah, D., Risnawati, \& Amir, Z. (2018). Pengembangan modul bebasis pendekatan konstruktivisme untuk memfasilitasi pemahaman konsep matematis siswa Sekolah Menengah Atas di Pekanbaru. Juring: Journal for Research in Mathematic Learning, 1(3), 199-206.

Setiawan, H. (2016). Pengembangan bahan ajar matematika bab integral berbasis konstruktivis pada siswa kelas XII IPA. Jurnal Inovasi, 18(2), 31-40.

Siagian, M. D. (2017). Pembelajaran matematika dalam perspektif konstruktivisme. Jurnal Pendidikan Islam dan Teknologi Pendidikan, VII(2), 61-73. Retrieved from http:jurnaltarbiyah.uinsu.ac.id/index.php/nizhamiyah/article/download/188/17 5.

Siahaan, F. B. (2005). Pembelajaran matematika menurut teori belajar konstruktivisme. Jurnal Ilmiah Best, 07(01), 16-22.

Siswono, T. Y. E. (2019). Paradigma penelitian pendidikan (Cetakan I). Bandung: PT Remaja Rosdakarya.

Subandi. (2013). Supervisi pendidikan untuk pengembangan profesionalitas guru berkelanjutan. Pedagogi Jurnal Ilmu Pendidikan, XIII(2), 1-9.

Sugiyono. (2015). Metode penelitian kuantitatif, kualitatif, dan R\&D. Bandung: Alfabeta

Sumarsih. (2009). Implementasi teori pembelajaran konstruktivistik dalam pembelajaran mata kuliah dasar-dasar bisnis. Jurnal Pendidikan Akuntansi Indonesia, VIII(1), 5462.

Uliana, R. G. (2016). Pengembangan bahan ajar matematika untuk siswa SMP berdasarkan teori belajar Ausubel. Pythagoras: Jurnal Pendidikan Matematika, 11(2), 163-191. https://doi.org/10.21831/pg.v11i2.10644. 